\title{
The influence of cooperative learning models on learning outcomes based on students' learning styles
}

\author{
Abdul Rahman, Ansari S. Ahmar \& Rusli \\ Universitas Negeri Makassar \\ Makassar, South Sulawesi, Indonesia
}

\begin{abstract}
This article reports on quasi-experimental research. The aims of this research were to examine: 1) which model of cooperative learning (TAI or STAD) is suitable for improving student learning outcomes; 2) whether the learning outcomes of mathematics students who have a visual learning style taught by the TAI type model is better than when they are taught with the STAD model; 3) whether the learning outcomes of mathematics students who have an auditory learning style taught by the TAI type model are better than when they are taught with the STAD model; 4) whether the learning outcomes of mathematics students who have a kinaesthetic learning style taught by the TAI type model are better than when they are taught with the STAD model; and 5) whether the learning outcomes of students who have a visual learning style are better than for students with an auditory or kinaesthetic learning style. The results of the learning outcomes of mathematics by students who were taught by the TAI and STAD cooperative learning model types show that there are no significant differences in terms of the visual, auditory and kinaesthetic learning styles.
\end{abstract}

\section{INTRODUCTION}

Education is a conscious and deliberate effort to create an atmosphere of learning and the learning process, so that students are actively developing the potential to have the spiritual power of religion, self-control, personality, intelligence, noble character and skills needed in society, the nation and the state (Constitution of Indonesia Number 20 Year of 2003) [1]. One cause of low learning outcomes is associated with learning models. Cooperative learning stimulates the activities that lead to cognitive students and promote higher levels of achievement and knowledge retention [2].

Learning models are often a cooperative learning models. There are many types, including the teams assisted individualisation (TAI) and student team achievement division (STAD) models [3-6]. The TAI type of cooperative learning model was developed by Slavin [7]. This type combines the advantages of cooperative learning and individual learning. It is designed to work on individual student learning difficulties. Therefore, learning activities more widely used for solving the problem, the hallmark of the TAI type model is built around any student learning from teaching materials prepared by the teacher. Individual learning outcomes are brought to the groups that have been formed to discuss the overall response as a shared responsibility.

The STAD type of learning cooperative model is the simplest type, and is suitable for use by teachers who are just beginning to use cooperative learning. In the STAD type, students are placed into learning teams of four, selected according to their performance level, gender and ethnicity. The teacher presents a lesson and, then, students work in teams to ensure that all team members have mastered the lesson. Eventually, all students are subjected individually to a quiz on the material in the record.

In addition to the learning model, another important factor in determining the outcome of students' mathematics learning is learning style. Learning style is the way the nature of the individual predisposes him/her to acquire and absorb information in their environment. Learning styles affect the learning process of individuals and should be taken into consideration in designing learning. There are three learning modalities: visual, auditory and kinaesthetic (VAK) [8][9].

Some research has indicated that the application of learning models needs to take into consideration the student's learning style, because the application of learning models that correspond to students' learning styles will encourage the achievement of maximum learning results [10]. When teachers and students understand the diversity of learning styles, which are then applied to the methods of learning and teaching, it will enable students to be more successful in learning. Brostöm and Lassen report that understanding the learning style of each student has been proved to increase awareness, flexibility and the ability to work in groups [11]. 
Given the importance of accuracy in selecting teachers according to the foregoing, the appropriate learning models have been applied to each student's learning style; hence, this study examines whether the application of cooperative learning and learning styles has any influence on students' learning outcomes.

\section{DEFINITIONS}

The cooperative learning model is a model of learning in which students work in small groups to help each other in learning the subject matter [6]. Cooperative learning model prioritises cooperation in solving problems to apply knowledge and skills in order to achieve learning objectives. Cooperative learning can be regarded as a learning process that does not have to come from the teacher to the students, but can also come from the students themselves who teach other students in the form of peer teaching [12]. One possible explanation of the success of cooperative learning is that cooperative learning is effective learning and often occurs through the interaction of individuals with their environment and language in the sense of learning and making students aware of it [13].

Team assisted individualisation (TAI) is a type of cooperative learning developed by Slavin [7]. This type combines the advantages of cooperative learning and individual learning. It is designed to address individual student learning difficulties. Therefore, learning activities are more widely used for troubleshooting. Characteristic of this type of TAI is that any individual student learning instructional material that has been prepared by the teacher [7]. Individual learning outcomes are brought to the groups that have been formed to discuss the overall response as a shared responsibility.

Student team achievement divisions (STAD) is one of the simplest types of cooperative learning [14]. Students are placed in learning teams of four people, selected according to their performance level, gender and ethnicity. Cooperative learning model in the STAD type emphasises the activity and interaction among students to motivate each other and help each other in mastering the subject matter in order to achieve maximum performance. Heterogeneous groups of members consisting of a random basis of selection according to their gender and ethnicity (diversity) [6].

Learning style is a combination of how the learners organise information, and how they process it [15]. Dunn defines learning styles as a student's capacity to process and retain new information [16]. Learning styles depend on the development of one's personality and are influenced by environmental, emotional, social influences and individuals' feelings. As a result, an instruction can be effective for some learners, but are not effective for other students because of their different learning styles. There are three learning modalities: visual, auditory and kinaesthetic (VAK) [8][9].

Visual learning style (visual) is a learning style through which people learn best when they see the images they are learning about, and can learn through reading. Visual learners think in pictures and learn best in visual images. They rely on nonverbal cues from the instructor or facilitator e.g. body language to help the process of understanding. Sometimes, visual learners prefer to sit in front of the class [9].

Individuals who have good visual learning ability are characterised by the following behavioural traits [15]: they are a) neat and tidy; b) speak quickly; c) plan and regulate long-term good; d) meticulous to detail; e) concerned with their appearance, both in terms of clothing and presentation; f) good spellers and can see the actual words in their minds; and g) taken by what is seen rather than what is heard.

The auditory learning style is one in which people learn better when they hear what they are learning about. Generally, people learn to use their hearing and tend to be interdependent [17]. Individuals who have good auditory learning abilities can be characterised by the following behavioural traits [15]: a) talking to oneself at work; b) being easily distracted by a commotion; c) moving their lips and saying what is written in a book when reading; d) being glad to read aloud and listen; e) being able to repeat back and mimic the tone, rhythm and timbre; f) finding it difficult to write, but being a good storyteller; and g) speaking in a patterned rhythm.

The kinaesthetic learning style is a learning style based on engaging, moving, experiencing and experimenting [17]. Individuals who have good kinaesthetic learning ability are characterised by the following behavioural traits [15]: a) speaking slowly; b) responding to physical attention; c) touching people to get their attention; d) standing close when talking to people; e) always being physically oriented and moving a lot; f) having the early development of large muscles; and g) learning through manipulation and practice.

\section{METHODS}

This research is based on a quasi-experimental design. The study involved two experimental class. Experimental Group I was taught by implementing the TAI type of cooperative learning model and Experimental Group II was taught by implementing a STAD type of cooperative learning model. The population in this study were all students of class $\mathrm{X}$ Senior High School 3 Makassar, Indonesia, in academic year 2014/2015. The sampling method used in this study was a cluster random sampling. If the population is scattered in some areas (clusters), each of which has the same characteristics, so one cluster can be taken at random as samples [18].

The design used in this study was based on post-test only control group design, which is described as follows [19]: 


$\begin{array}{lll}\mathrm{R} & \mathrm{X} & \mathrm{O}_{1} \\ \mathrm{R} & & \mathrm{O}_{2}\end{array}$

where:

$\mathrm{R}=$ random;

$\mathrm{X}=$ treatment;

$\mathrm{O}_{1}=$ classes are taught cooperative learning model of TAI type;

$\mathrm{O}_{2}=$ classes are taught cooperative learning model of STAD type.

\section{RESULTS AND DISCUSSION}

Differences in Learning Outcomes of Mathematics Students Taught through the Implementation of TAI Type and STAD Type of Cooperative Learning Models

This study aimed to determine the effect of the model of applied learning in class X SMA Negeri 3 Makassar, the cooperative TAI type and STAD type of cooperative learning models taking into account the students' visual, auditory and kinaesthetic (VAK) learning styles. After the learning process, students were tested for mathematics achievement and test results were, then, analysed using SPSS version 20.

Table 1: Independent samples test for study results of students taught by TAI and STAD (independent samples test).

\begin{tabular}{|c|c|c|c|c|c|c|c|c|c|c|}
\hline & \multicolumn{2}{|c|}{$\begin{array}{l}\text { Levene's test } \\
\text { for equality of } \\
\text { variances }\end{array}$} & \multicolumn{7}{|c|}{$T$-test for equality of means } \\
\hline & & \multirow[t]{2}{*}{$\mathrm{F}$} & \multirow[t]{2}{*}{ Sig. } & \multirow[t]{2}{*}{$t$} & \multirow[t]{2}{*}{$\mathrm{df}$} & \multirow[t]{2}{*}{$\begin{array}{c}\text { Sig. } \\
\text { (2-tailed) }\end{array}$} & \multirow[t]{2}{*}{$\begin{array}{c}\text { Mean } \\
\text { difference }\end{array}$} & \multirow[t]{2}{*}{$\begin{array}{l}\text { Std. error } \\
\text { difference }\end{array}$} & \multicolumn{2}{|c|}{$\begin{array}{c}\text { 95\% confidence } \\
\text { interval of the } \\
\text { difference }\end{array}$} \\
\hline & & & & & & & & & Lower & Upper \\
\hline \multirow{2}{*}{$\begin{array}{l}\text { Learning } \\
\text { outcomes }\end{array}$} & $\begin{array}{l}\text { Equal } \\
\text { variances } \\
\text { assumed }\end{array}$ & 0.548 & 0.462 & 0.777 & 67.0 & 0.440 & 1.683 & 2.166 & -2.640 & 6.006 \\
\hline & $\begin{array}{l}\text { Equal } \\
\text { variances not } \\
\text { assumed }\end{array}$ & & & 0.776 & 65.5 & 0.441 & 1.683 & 2.170 & -2.650 & 6.016 \\
\hline
\end{tabular}

Table 2: Two-way ANOVA test for study results of students taught by TAI and STAD (tests of between-subjects effects).

Dependent variable: Learning outcomes

\begin{tabular}{|l|c|c|c|c|c|}
\hline Source & Type III sum of squares & df & Mean square & F & Sig. \\
\hline Corrected Model & $284.375^{*}$ & 5 & 56.875 & 0.691 & 0.632 \\
\hline Intercept & 425689.275 & 1 & 425689.275 & 5171.917 & 0.000 \\
\hline STYLES & 56.876 & 2 & 28.438 & 0.346 & 0.709 \\
\hline MODEL & 66.133 & 1 & 66.133 & 0.803 & 0.373 \\
\hline STYLES* MODEL & 178.306 & 2 & 89.153 & 1.083 & 0.345 \\
\hline Error & 5185.393 & 63 & 82.308 & & \\
\hline Total & 468770.000 & 69 & & & \\
\hline Corrected Total & 5469.768 & 68 & & & \\
\hline
\end{tabular}

* $\mathrm{R}$ squared $=0,052$ (adjusted $\mathrm{R}$ squared $=-0,023$ )

Based on the results of inferential analysis (Table 1), there is no difference between the learning outcomes of students taught by the TAI type of cooperative learning model team and the STAD type of cooperative learning model.

Also, based on the test results two-way ANOVA (Table 2), it has been shown that there is no significant relationship between learning model learning styles.

From the results of the descriptive analysis (Table 3), it appears that learning with the TAI type of cooperative learning model, student achievement (Mean) is slightly higher than with the STAD type of cooperative learning model.

Table 3: Descriptive statistics for study results of students taught by TAI and STAD (group statistics).

\begin{tabular}{|l|l|c|c|c|c|}
\hline & Cooperative model & $\mathrm{N}$ & Mean & Std. deviation & Std. error mean \\
\hline \multirow{2}{*}{$\begin{array}{l}\text { Learning } \\
\text { outcomes }\end{array}$} & TAI & 35 & 82.77 & 8.437 & 1.426 \\
\cline { 2 - 6 } & STAD & 34 & 81.09 & 9.536 & 1.635 \\
\hline
\end{tabular}


Differences in Learning Outcomes of Mathematics Students Taught through the Implementation of TAI or STAD Types of Cooperative Learning based on the Visual Learning Style

Based on the results obtained through inferential analysis, the results of students learning mathematics taught through the implementation of TAI or STAD types of cooperative learning model in terms of visual learning styles did not produce a significant difference. However, when viewed as descriptive statistics, there are differences in the average value of student learning outcomes that are taught through the implementation of these cooperative learning models.

Table 4: Independent samples test for study results of students taught by TAI and STAD based on the visual learning style (independent samples test).

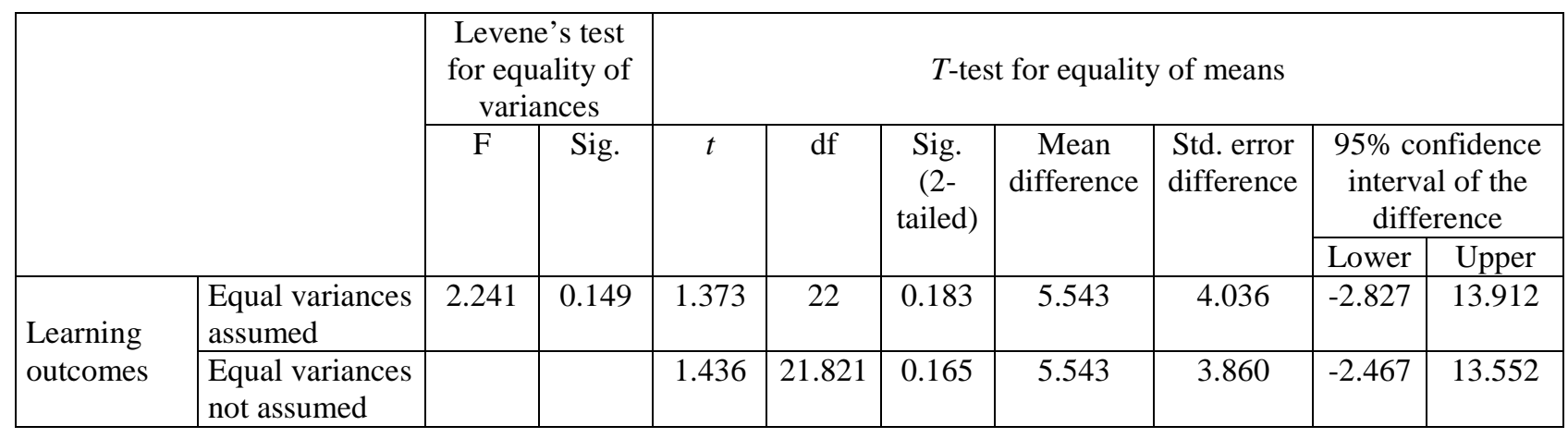

Table 5: Descriptive statistics for study results of students taught by TAI and STAD based on the visual learning style (group statistics).

\begin{tabular}{|l|l|c|c|c|c|}
\hline & Cooperative model & $\mathrm{N}$ & Mean & Std. deviation & Std. error mean \\
\hline \multirow{2}{*}{$\begin{array}{l}\text { Learning } \\
\text { outcomes }\end{array}$} & TAI & 14 & 83.14 & 10.676 & 2.853 \\
\cline { 2 - 6 } & STAD & 10 & 77.60 & 8.222 & 2.600 \\
\hline
\end{tabular}

The results (Tables 4 and 5) obtained show that the learning outcomes of students who are taught through the implementation of the TAI type of cooperative learning model are higher than those taught through the STAD type. This is because the TAI type combines individual learning with group learning, through which students are given the opportunity to read/learn the material that has been prepared by the teacher. Students were then given a quiz individually, and the results of individual students' work was then aggregated into their group. The differences between the average values for each type of learning was not significant.

Difference of Mathematics Learning Outcomes of Students Taught through the Implementation of TAI and STAD Types of Cooperative Learning Model based on the Auditory Learning Style

Based on the results obtained through inferential analysis (Table 6), the results of mathematics students who are taught through the implementation of TAI type and STAD type of cooperative learning models in terms of auditory learning styles were not significantly different. However, when viewed as descriptive statistics (Table 7), there are differences in the average value of student learning outcomes between the two models. The results obtained show that the learning outcomes of students who were taught through the implementation of the TAI type of cooperative learning model were higher than those taught through the STAD type. This is because the TAI type of cooperative learning model combines individual learning with group learning. Students who have a better understanding of the material are responsible for helping friends in the other group.

Table 6: Independent samples test for study results of students taught by TAI and STAD based on the auditory learning style (independent samples test).

\begin{tabular}{|c|c|c|c|c|c|c|c|c|c|c|}
\hline & \multicolumn{2}{|c|}{$\begin{array}{l}\text { Levene's test } \\
\text { for equality of } \\
\text { variances }\end{array}$} & \multicolumn{7}{|c|}{$T$-test for equality of means } \\
\hline & & \multirow[t]{2}{*}{$\mathrm{F}$} & \multirow[t]{2}{*}{ Sig. } & \multirow[t]{2}{*}{$t$} & \multirow[t]{2}{*}{ df } & \multirow[t]{2}{*}{$\begin{array}{l}\text { Sig. (2- } \\
\text { tailed) }\end{array}$} & \multirow[t]{2}{*}{$\begin{array}{c}\text { Mean } \\
\text { difference }\end{array}$} & \multirow[t]{2}{*}{$\begin{array}{l}\text { Std. error } \\
\text { difference }\end{array}$} & \multicolumn{2}{|c|}{$\begin{array}{c}\text { 95\% confidence } \\
\text { interval of the } \\
\text { difference }\end{array}$} \\
\hline & & & & & & & & & Lower & Upper \\
\hline \multirow{2}{*}{$\begin{array}{l}\text { Learning } \\
\text { outcomes }\end{array}$} & $\begin{array}{l}\text { Equal variances } \\
\text { assumed }\end{array}$ & 2.772 & 0.108 & $\begin{array}{c}- \\
0.598\end{array}$ & 25 & 0.555 & -2.059 & 3.442 & -9.148 & 5.030 \\
\hline & $\begin{array}{l}\text { Equal variances } \\
\text { not assumed }\end{array}$ & & & $\begin{array}{c}- \\
0.680\end{array}$ & 24.97 & 0.503 & -2.059 & 3.029 & -8.298 & 4.180 \\
\hline
\end{tabular}


Table 7: Descriptive statistics for study results of students taught by TAI and STAD based on the auditory learning style (group statistics).

\begin{tabular}{|l|l|c|c|c|c|}
\hline & Cooperative model & $\mathrm{N}$ & Mean & Std. deviation & Std. error mean \\
\hline \multirow{2}{*}{$\begin{array}{l}\text { Learning } \\
\text { outcomes }\end{array}$} & TAI & 10 & 81.00 & 5.888 & 1.862 \\
\cline { 2 - 6 } & STAD & 17 & 83.06 & 9.852 & 2.389 \\
\hline
\end{tabular}

Difference of Mathematics Learning Outcomes of Students Taught through the Implementation of Cooperative Learning Model of TAI Type and STAD Type based on the Kinaesthetic Learning Style

Based on the results of inferential analysis (Table 8), the differences in results of mathematics students who were taught through the TAI and STAD types of cooperative learning models were not significant. However, when viewed as descriptive statistics (Table 9), there were differences in the average value of student learning. The results obtained show that the learning outcomes of students who were taught through the implementation of the TAI type of cooperative learning model are higher than those taught through the STAD type. This is because the TAI type of cooperative learning model combines individual learning groups, so that each student feels responsible for understanding the material well. The points obtained from the quiz determine the extent to which the success of any group in understanding the material.

Table 8: Independent samples test for study results of students taught by TAI and STAD based on the kinaesthetic learning style (independent samples test).

\begin{tabular}{|c|c|c|c|c|c|c|c|c|c|c|}
\hline & \multicolumn{2}{|c|}{$\begin{array}{l}\text { Levene’s test } \\
\text { for equality } \\
\text { of variances }\end{array}$} & \multicolumn{7}{|c|}{$T$-test for equality of means } \\
\hline & & \multirow[t]{2}{*}{$\mathrm{F}$} & \multirow[t]{2}{*}{ Sig. } & \multirow[t]{2}{*}{$t$} & \multirow[t]{2}{*}{ df } & \multirow[t]{2}{*}{$\begin{array}{l}\text { Sig. (2- } \\
\text { tailed) }\end{array}$} & \multirow[t]{2}{*}{$\begin{array}{c}\text { Mean } \\
\text { difference }\end{array}$} & \multirow[t]{2}{*}{$\begin{array}{l}\text { Std. error } \\
\text { difference }\end{array}$} & \multicolumn{2}{|c|}{$\begin{array}{c}95 \% \text { confidence } \\
\text { interval of the } \\
\text { difference }\end{array}$} \\
\hline & & & & & & & & & Lower & Upper \\
\hline \multirow{2}{*}{$\begin{array}{l}\text { Learning } \\
\text { outcomes }\end{array}$} & $\begin{array}{l}\text { Equal variances } \\
\text { assumed }\end{array}$ & 1.480 & 0.241 & 0.619 & 16 & 0.545 & 2.623 & 4.240 & -6.365 & $\begin{array}{c}11.61 \\
1\end{array}$ \\
\hline & $\begin{array}{l}\text { Equal variances } \\
\text { not assumed }\end{array}$ & & & 0.576 & 10.07 & 0.578 & 2.623 & 4.558 & -7.523 & $\begin{array}{c}12.76 \\
9\end{array}$ \\
\hline
\end{tabular}

Table 9: Descriptive statistics for study results of students taught by TAI and STAD based on kinaesthetic learning style (group statistics).

\begin{tabular}{|l|l|c|c|c|c|}
\hline & Cooperative model & $\mathrm{N}$ & Mean & Std. deviation & Std. error mean \\
\hline \multirow{2}{*}{$\begin{array}{l}\text { Learning } \\
\text { outcomes }\end{array}$} & TAI & 11 & 83.91 & 7.609 & 2.294 \\
\cline { 2 - 6 } & STAD & 7 & 81.29 & 10.420 & 3.938 \\
\hline
\end{tabular}

Difference of Results in Students’ Mathematics Learning Style based on Visual, Auditory and Kinaesthetic Styles

Based on the results obtained through inferential analysis (Table 10), the results of students' mathematics learning style show that there is no significant difference between those that learn through visual, auditory and kinaesthetic styles. However, when viewed as descriptive statistics (Table 11), there are differences in the average value of student learning outcomes of visual, auditory and kinaesthetic styles. The results showed that the students' learning outcomes in the auditory learning style was higher than the results of the students' mathematics visual learning and kinaesthetic learning style.

Table 10: One-way ANOVA test for study results of students based on visual, auditory and kinaesthetic learning styles ANOVA (learning outcomes).

\begin{tabular}{|l|c|c|c|c|c|}
\hline & Sum of squares & df & Mean square & F & Sig. \\
\hline Between groups & 49.027 & 2 & 24.514 & 0.298 & 0.743 \\
\hline Within groups & 5420.741 & 66 & 82.132 & & \\
\hline Total & 5469.768 & 68 & & & \\
\hline
\end{tabular}

Table 11: Descriptive statistics for study results of students based on visual, auditory and kinaesthetic learning styles (learning outcomes).

\begin{tabular}{|c|c|c|c|c|c|c|c|c|}
\hline & \multirow{2}{*}{$\mathrm{N}$} & \multirow{2}{*}{ Mean } & \multirow{2}{*}{$\begin{array}{c}\text { Std. } \\
\text { deviation }\end{array}$} & \multirow{2}{*}{$\begin{array}{l}\text { Std. } \\
\text { Error }\end{array}$} & \multicolumn{2}{|c|}{ 95\% confidence interval for mean } & \multirow{2}{*}{ Minimum } & \multirow{2}{*}{ Maximum } \\
\hline & & & & & Lower bound & Upper bound & & \\
\hline Visual & 24 & 80.83 & 9.933 & 2.028 & 76.64 & 85.03 & 66 & 95 \\
\hline Auditory & 27 & 82.30 & 8.530 & 1.642 & 78.92 & 85.67 & 67 & 95 \\
\hline Kinaesthetic & 18 & 82.89 & 8.608 & 2.029 & 78.61 & 87.17 & 67 & 95 \\
\hline Total & 69 & 81.94 & 8.969 & 1.080 & 79.79 & 84.10 & 66 & 95 \\
\hline
\end{tabular}




\section{CONCLUSIONS}

The results showed that: 1) there are no significant differences in the learning outcomes of mathematics students when taught through the TAI or STAD type of cooperative learning models, in terms of visual, auditory or kinaesthetic learning styles; and that 2) according to the descriptive statistics, the student learning outcomes of mathematics students from the auditory learning style are better than those achieved through the visual and kinaesthetic learning styles. Some things are better done by the teacher, so that they understand the learning style of each student. This would assist teachers in preparing a learning model that suits the teacher and can improve student learning outcomes.

It is expected that through the results of this research, every teacher would be able to encourage each student to recognise and grasp the learning style that is suitable for them.

\section{REFERENCES}

1. Republic of Indonesia. Constitution of Indonesia Number 20 Year of 2003 (2003).

2. Tran, V.D., The effects of cooperative learning on the academic achievement and knowledge retention. Inter. J. of Higher Educ., 3, 2, 131-140 (2014).

3. Bukunola, B.J. and Idowu, O.D., Effectiveness of cooperative learning strategies on Nigerian junior secondary students' academic achievement in basic science. The J. of Educ. Research, 2, 3, 307-325 (2012).

4. Gupta, M., Jain, M. and Pasrija, P., Gender related effects of co-operative learning strategies (STAD and TAI) on mathematics achievement. Issues and Ideas in Educ., 2, 1, 53-68 (2014).

5. Slavin, R.E., When does cooperative learning increase student achievement? Psychol. Bull., 94, 3, 429-445 (1983).

6. van Wyk, M., The effects of the STAD-cooperative learning method on student achievement, attitude and motivation in economics education. Educ. J., 33, 2, 261-270 (2012).

7. Slavin, R.E., Cooperative Learning: Theory, Research, and Practice. (2nd Edn). Boston: Allyn \& Bacon (1995).

8. Gholami, S. and Bagheri, M.S., Relationship between VAK learning styles and problem solving styles regarding gender and students' fields of study. J. of Lang. Teach. and Research., 4, 4, 700-706 (2013).

9. Gilakjani, A.P. and Ahmadi, S.M., The effect of visual, auditory, and kinaesthetic learning styles on language teaching. Proc. Inter. Conf. on Social Science and Huminity, Singapore, 469-472 (2011).

10. Ahriani, F., Influence of Cooperative Learning Model and Learning Styles on Chemistry Learning Outcomes of Students Class X SMK Negeri 2 Bantaeng (Pengaruh model pembelajaran kooperatif dan gaya belajar terhadap hasil belajar kimia peserta didik kelas X SMK Negeri 2 Bantaeng). Master Thesis. Universitas Negeri Makassar, Indonesia (2013) (in Indonesian).

11. Boström, L. and Lassen, L.M., Unraveling learning, learning styles, learning strategies and meta-cognition. Educ. Train., 48, 2, 178-189 (2006).

12. Marsono, Development of a cooperative micro lesson study learning model to teaching creatively and teaching for the creativity of engineering students. World Trans. on Engng. and Technol. Educ., 14, 2, 322-326 (2016).

13. Tsay, M. and Brady, M., A case study of cooperative learning and communication pedagogy: does working in teams make a difference? J. of the Scholarship of Teaching and Learning, 10, 2, 78-89 (2010).

14. Moore, K.D., Effective Instructional Strategies: From Theory to Practice. USA: SAGE Publications (2014).

15. DePorter, B. and Hernacki, M., Quantum Learning. New York, USA: Dell Paperbacks (2002).

16. Dunn, R., How to Implement and Supervise a Learning Styles Program. Alexandria, VA: Association for Supervision and Curriculum Development (1996).

17. Widiyanti, T., The Influence of Learning Styles on Mathematical Problem Solving Ability (Pengaruh gaya belajar terhadap kemampuan pemecahan masalah matematika) (2011). Master Thesis. 19 June 2015, (in Indonesian), http://repository.uinjkt.ac.id/dspace/bitstream/123456789/5755/1/TETI\%20 WIDIYANTI-FITK.

18. Gulo, W., Research Method (Metodologi Penelitian). Jakarta, Indonesia: Gramedia (2004).

19. Sugiyono, S., Research Methods of Qualitative, Quantitative, and R\&D (Metode penelitian kuantitatif, kualitatif dan, $R \& D)$. Bandung, Indonesia: Alfabeta (2006) (in Indonesian). 